\title{
Pancasila Values in the Business Event Against Entrepreneurial Attitudes
}

\author{
Monalisa \\ Universitas Sebelas Maret, Kota Surakarta, Indonesia \\ monalisapurba98@gmail.com
}

\section{Article History}

accepted 23/03/2021

approved 10/04/2021

published 20/04/2021

\begin{abstract}
This study examines the importance of Pancasila values in the field of entrepreneurship and the method used in this research is the case study method. Pancasila is the ideology of the Indonesian nation which includes important values to be applied in the world of entrepreneurship. In a business event, such as the simplypopupmarket event which was held during the Covid-19 pandemic, namely the Nummy Local brand (Hanum Mega), Hair Repair (Audi Marisa) and other brands without being based on Pancasila values, business events will easily split. An entrepreneur or brand owner must be based on the values of Pancasila. When an event is held by an event program owner, a brand owner not only sees other brands or other booths as a threat to himself, but sees that the booth is his business partner so that all local products can compete together without destroying national unity and unity. . As was done by Audi Marisa (Hair Repair) as well as public figures who visited each booth at the event. at the same time buying other products to support local products to remain victorious in Indonesia. A good entrepreneur is a person who struggles based on the values of Pancasila.
\end{abstract}

Keywords: value, Pancasila, event, business, attitude, entrepreneurship

\section{Abstrak}

Studi ini mengkaji tentang pentingnya nilai-nilai Pancasila dalam bidang kewirausahawan dan metode yang digunakan dalam penelitian ini adalah metode studi kasus. Pancasila merupakan ideologi bangsa Indonesia yang di dalamnya mencangkup nilai-nilai yang penting untuk di terapkan dalam dunia berwirausaha. Pada suatu Event Bussiness, seperti Event simplypopupmarket yang diadakan pada masa pandemi covid-19 yaitu brand Nummy Local (Hanum Mega), Hair Repair (Audi Marisa) dan brand lainnya tanpa dilandaskan nilai-nilai Pancasila, Event bisnis akan mudah terjadi perpecahan. Seorang wirausaha atau pemilik brand harus dilandaskan pada nilai-nilai Pancasila. Ketika diselenggarakan sebuah event oleh suatu pemilik program event, seorang pemilik brand tidak hanya melihat brand lain atau booth lain sebagai ancaman untuk dirinya, tetapi melihat bahwa booth tersebut sebagai partner bisnisnya supaya semua produk lokal dapat bersaing bersama-sama tanpa harus menghancurkan kesatuan dan persatuan bangsa. Seperti yang dilakukan oleh Audi Marisa (Hair Repair) sekaligus tokoh publik yang mengunjungi masing-masing booth yang ada di Event tersebut. sekaligus membeli produk lain untuk mendukung produk lokal tetap berjaya di Indonesia. Seorang Wirausaha yang baik adalah orang yang berjuang dengan berlandasan nilai-nilai Pancasila.

Kata Kunci : nilai, Pancasila, event, bussiness, sikap, berwirausaha

Social, Humanities, and Education Studies (SHEs): Conference Series https://jurnal.uns.ac.id/shes

p-ISSN 2620-9284

e-ISSN 2620-9292 


\section{PENDAHULUAN}

Perubahan dunia begitu cepat sehingga mengakibatkan setiap langkah harus berubah cepat menuju arah yang lebih baik. Perubahan akan mempengaruhi berbagai bidang, baik bidang sosial, budaya maupun ekonomi yang mengakibatkan keterkaitan antara bidang satu dengan yang lain pun ikut berubah. Seseorang akan kalah dengan keadaan global ini jika tidak mengantisipasinya dengan baik dan tepat. Sehingga perlu kreativitas, komunikasi, kolaborasi dalam memecahkan masalah. Begitu juga dengan kewirausahaan, kesuksesan orang berbisnis tanpa kolaborasi, baik dengan masyarakat ataupun teman sejawat tidak mungkin berhasil.

Menurut Kasmir (2016:28) Adapun sikap dan perilaku yang harus dijalankan oleh pengusaha dan seluruh karyawan adalah 1) Jujur dalam bertindak dan bersikap, 2) Rajin, tepat waktu dan tidak pemalas, 3) Selalu murah senyum, 4) Lemah lembut dan ramah-tamah, 5) Sopan santun dan hormat, 6) Selalu ceria dan pandai bergaul, 7) Fleksibel dan suka menolong, 8) Serius dan memiliki tanggung jawab, 9) Rasa memiliki perusahaan yang tinggi.

Event Bussines merupakan penyelenggaraan acara yang mengumpulkan semua partisipan pengusaha atau pemegang brand untuk bersaing menunjukkan kualitas produknya masing-masing.Biasanya Even Bussines ini setiap pengusaha mempunyai booth tersendiri yang sudah ditentukan. Booth tersebut dinamakan stand pertunjukan atau pameran. Dalam penjagaan stand, selain di jagai pengusaha produk itu sendiri, mereka dibantu oleh pegawai-pegawainya. Event Bussnies yang saya amati secara via online media sosial instagram pada masa pandemi covid-19 yaitu Event simplypopupmarket, Even ini dilakukan di Grand Indonesia awal bulan maret ini dengan menjaga jarak antar stand dan tetap melakukan protokol kesehatan. Peserta atau partisipasi event yang paling muncul adalah tokoh publik. Tokoh publik tersebut Audi Marisa. Seorang tokoh publik yang mempunyai produk kecantikan, hasil colaborasi dengan Hair Repair dan brand quokkabeauty. Serta selebgram Hanum Mega pemilik brand Nummy Local.

Pancasila merupakan ideologi bangsa Indonesia yang dihasilkan melalui nilainilai perjuangan, nilai-nilai luhur, dinamika sosial dan budaya. Dalam era global di masa pandemi covid-19 ini, masyarakat Indonesia harus mendapatkan perhatian serius karena dinamika global dapat menyebabkan pergeseran nilai-nilai luhur secara mendasar yang dapat merusak pondasi bangsa Indonesia secara menyeluruh. Tanpa di sadari proses global ini dapat membawa masyarakat Indonesia menuju permasalahan yang komplek baik dari aspek ekonomi, sosial, politik, budaya, dimensi agama dan hukum. Ditambah lagi dengan adanya wabah covid-19 ini dari bidang kesehatan.

Nilai-nilai Pancasila berkaitan dengan karakter masyarakat, karena nilai-nilai Pancasila tercermin jati diri masyarakat Indonesia. Hal ini perlu diwariskan kepada generasi muda bangsa Indonesia sebagai pedoman hidup. Dengan berpedoman Pancasila, para pengusaha atau pemilik brand harus berpedoman pada Pancasila. Sehingga semua produk-produk lokal bisa berjuang bersama-sama tanpa menjatuhkan saudara setanah airnya sendiri. Hal inilah merupakan sikap berwirausaha yang menanamkan nilai-nilai Pancasila.

\section{Landasan Teori}

(Ubaidillah, 2000) megemukakan bahwa Ideologi memainkan peranan yang penting dalam proses dan memelihara integrasi nasional, terutama di Negara-negara yang sedang berkembang seperti Indonesia. Pancasila sebagai dasar negara rumusan materinya tertuang dalam Pembukaan UUD 1945 alinea keempat (Budiarto, 189): "........... maka disusunlah Kemerdekaan Kebangsaan Indonesia dalam suatu UndangUndang Dasar Negara Indonesia, yang terbentuk dalam suatu susunan Negara Republik Indonesia, yang berkedaulatan rakyat dengan berdasarkan kepada: Ketuhanan Yang Maha Esa, Kemanusiaan yang adil dan beradab, persatuan 
Indonesia dan kerakyatan yang dipimpin oleh hikmat kebijaksanaan dalam permusyawaratan/ perwakilan, serta dengan mewujudkan suatu keadilan sosial bagi seluruh rakyat Indonesia."

Sri Untari (2012) menjabarkan fungsi Pancasila antara lain: 1) sebagai identitas dan kepribadian bangsa, 2) sebagai sistem filsafat Pancasila bersifat obyektif ilmiah, karena uraiannya bersifat logis dan dapat diterima oleh paham yang lain, 3) sebagai sumber nilai-nilai dasar Pancasila, yaitu nilai Ketuhanan, nilai kemanusiaan, nilai persatuan, nilai kerakyatan, nilai keadilan, 4) sistem etika dan norma, 5) sebagai paradigma keilmuan ekonomi, politik, hukum, pendidikan, 6) Ideologi terbuka.

Pancasila dalam kehidupan sehari-hari, dimulai dari kegiatan-kegiatan sederhana yang menggambarkan hadirnya nilai-nilai Pancasila dalam masyarakat. Misalnya, masyarakat selalu bahu-membahu dalam ikut berpartisipasi, saling menolong, dan menjaga satu sama lain. Hal ini mengindikasikan bahwa nilai-nilai Pancasila telah terinternalisasi dalam kehidupan bermasyarakat. (Ayu, hlm 9)

Arus globalisasi tidak mungkin dihentikan. Berjalannya globalisasi tidak terlepas dari perkembangan ilmu pengetahuan dan teknologi sebagai penyebabnya. Dampaknya juga

\section{METODE}

Metode yang digunakan dalam penelitian ini adalah metode studi kasus kualitatif. Studi kasus pada Event Bussines yang diselenggarakan oleh simplypopupmarket. Proses pengumpulan data hingga pelaporan hasilnya dengan Observasi melalui media sosial instgram. Observasi terhadap perilaku orang atau proses kerja suatu produk yang dihasilkan dari penelitian dan pengembangan, dapat dilakukan oleh peneliti atau orang lain. Dalam melakukan pengamatan, peneliti melihat, dan mendengarkan (Sugiyono, 2019:215). Teknik analisis data dalam penelitian ini yaitu deskriptif analisis domain. Artinya peneliti melakukan penjelajah umum dan menyeluruh, melakukan deskripsi terhadap semua yang dilihat, didengar, dan dirasakan. Sehingga peneliti menghasilkan kesimpulan pertama.

\section{HASIL DAN PEMBAHASAN}

Sila kemanusiaan yang adil dan beradab, diwujudkan dalam bentuk perilaku yang saling menghargai harkat dan martabat manusia, kesamaan dalam kemasyrakatan dan hukum, saling mengasihi dan menyayangi satu sama lain hingga mewujudkan kondisi yang serasi dan selaras dalam masyarakat. Sila persatuan Indonesia, diwujudkan tiadanya diskriminasi individu dan antar golongan, kesediaan bekerjasama untuk kepentingan bersama, bergotong royong, rela berkorban, senantiasa sederajat untuk menciptakan kerukunan, mencintai karya bangsa sendiri dan lainnya. Serta sila kelima yaitu keadilan sosial bagi seluruh rakyat Indonesia, diwujudkan dalam bentuk perilaku menghargai hak orang lain, karya cipta orang lain, dan mengedepankan kewajiban dan hak yang dilaksanakan secara seimbang.

Sikap berwirausahaan ditunjukkan oleh Audi Marisa (tokoh publik) seperti selalu murah senyum (Audi dan Hanum),lemah lembu, ramah-tamah, Sopan santun kepada semua orang pengunjung atau pelanggannya, hormat kepada yang lebih tua (sila ke II dan ke V), selalu ceria dan pandai bergaul kepada pegawai-pegawai stand lainnya (sila ke III) artinya ada nilai kesatuan dalam event tersebut, Fleksibel dalam berpenampilan dan suka menolong (sila ke II) ia memiliki jiwa sosial yang tinggi dan beradab. Sila ke $V$ yaitu menghargai karya cipta orang lain. Sehingga ia membantu membeli sendiri produk-produk partisipan stand yang lain, baik UMKM (Usaha Mikro Kecil Menengah) ataupun pengusah yang masih merintis. Hal-hal diatas merupakan nilai-nilai Pancasila yang perlu ditanamkan pada masyarakat Indonesia. 
Nilai-nilai yang tercermin di Pancasila yang lainnya sebagai kearifan lokal adalah gotong royong atau kebersamaan. Hal tersebut dilakukan oleh tokoh publik yaitu Audi Marisa yang di upload di instagram @simplypopupmarket, ataupun instagram para pengunjung dan penjaga stand, ia mengunjungi stand lain, untuk membantu perekonomian sesama partisipan event.Nilai-nilai Pancasila dapat terciptanya kehidupan yang rukun, damai, dan tentram. Serta merdeka bersama-sama dalam bidang perekonomian.

\section{SIMPULAN}

Nilai-nilai Pancasila sebagian kecil dari masyarakat Indonesia sudah mengimplementasikannya kedalam kehidupannya. Salah satunya oleh tokoh publik yaitu Audi Marisa, ia sebagai pemegang 2 brand kecantikan (Hair Repair dan quokkabeauty) memegang nilai-nilai leluhur dan nilai perjuangan bangsa dengan menunjukkan kepeduliannya, keramah tamahnya dan sikap lainnya dalam berwirausaha. Serta membantu mengembangkan produk-produk lokal baik makanan, minuman ataupun produk lainnya. Selain itu juga membantu perekonomian bangsa Indonesia di masa global yang sulit ini yaitu masa pandemi covid-19. la mempunyai sikap berwirausaha dengan menekankan keegoisannya untuk dapat sukses sendiri, tetapi ia membantu membangkitkan produk lain atau partisipasi stand lain. Nilai-nilai inilah yang perlu diberikan atau ditekankan kepada generasi muda, baik yang mempunyai bisnis atau konsumen produk. Menjaga persatuan Indonesia yang telah diperjuangkan oleh pahlawan. 


\section{DAFTAR PUSTAKA}

Ambiro, P.A. (2017) "Menjaga Eksistensi Pancasila dan Penerapannya Bagi Masyarakat di Era Globalisasi". Jurnal Pancasila dan Kewarganegaraan, 2(1)

Kementerian Pendidikan Nasional. 2010. Desain Induk Pendidikan Karakter Kementrian Pendidikan Nasional. Jakarta: Kemendiknas.

M. Budiarto, "Pemberdayaan Pancasila Sebagai Dasar Negara dan Pandangan Hidup Bangsa Dalam Era Globalisasi (Aspek Yuridis Ketatanegaraan)", Bahan Ceramah "Continuing Legal Education" Badan Pembinaan Hukum Nasional, 2003, hlm. 189.

Septianingsi, Ayu, "Pentingnya Menerapkan Nilai-Nilai Pancasila Di Lingkungan Masyarakat". Jurnal UIN Banten.

Sri Untari. (2012). "Pancasila dalam Kehidupan Bermasyarakat Berbangsa, dan Bernegara" dalam Margono (Ed). Pendidikan Pancasila Topik Aktual Kenegaraan dan Kebangsaan. Malang: Universitas Negeri Malang (UM Press)".

Sugiyono. (2019). Metode Penelitian \& Pengembangan Research and Development. Alfabeta, Bandung.

Sutan, S.Z. (2016). Aktualisasi Nilai-Nilai Pancasila sebagai Dasar Falsafah Negara dan Implementasinya Dalam Pembangunan Karakter Bangsa. Jurnal Pendidikan IImu Sosial 26(2).

Ubaidiah, A, dkk. 2000. Pendidikan Kewarganegaraan (Civic Education), Demokrasi, HAM, \& Masyarakat Madani. Jakarta:IAIN Jakarta Press 